\title{
PROFITABILITY DETERMINANTS OF HOTEL INDUSTRY IN AP VOJVODINA
}

\author{
Branimir Kalaš $\check{\check{c}}^{1}$ \\ Vera Mirović ${ }^{2}$ \\ Nataša Pavlović ${ }^{3}$ (C)
}

DOI: https://doi.org/10.31410/tmt.2019.47

\begin{abstract}
The tourism sector in Vojvodina includes 220 hotels registered in AP Vojvodina in 45 municipalities and their performances have a significant role for development of tourism in this Province. The most hotels are concentrated in Novi Sad and Subotica, where hotels in these cities consist 40\% of total hotels in AP Vojvodina. The aim of this chapter is to analyze the profitability of hotels in AP Vojvodina in terms of modelling impact of internal factors. The chapter includes multivariate analysis of variance, as well as regression models which enable identifying profitability level of hotels and how liquidity, debt, financial stability, size and sale growth affect the profitability.
\end{abstract}

Keywords: profitability, internal factors, hotels, AP Vojvodina.

\section{INTRODUCTION}

$\mathrm{T}$ he tourism sector represents a significant potential of any national economy where increasing growth in tourism revenue has an important role in achieving macroeconomic goals and social welfare (Milenković, Andrašić, \& Kalaš, 2017).

Tourism industry in Serbia and countries in the region such as Hungary, Croatia, Slovenia and Romania manifest great interest in business tourism development. Namely, these countries continuously put new facilities on the market and compete in attracting international business events. According to Tourism Development Strategy which aims to achieve the increased competitiveness of Serbian tourism and identifies Vojvodina, Western Serbia and Easter Serbia as four major tourism clusters (Mašić, 2013). The Vojvodina Province represents an attractive location for holding business events and has a long tradition of organizing congresses and fairs (Dragićević, Jovičić, Blešić, Stankov, \& Bošković, 2012). Tourism in AP Vojvodina went through very different periods. After expansion between 1960 and the mid-1980s, there was a decline in tourists number and overnight in 1990 due to political and economic conditions. Since 2000, the number of tourists and overnight has increased, mostly by foreign tourists. According to the strategy of development program of the AP Vojvodina 2014-2020, as a result of Serbia openness to Europe, percentage of foreign tourists in total number of tourists visiting Serbia is increasing. Also, due to economic globalization, the rise in the number of foreign tourists has led to positive changes in the Serbia's economy, including the increased demand for Serbian hotels and the number of foreign hotel customers (Alčaković, Pavlović, \& Popesku, 2017).

The main reasons of expanding investment in the hotel industry are: a) the number of trained employees have increased, b) old hotels have been upgraded to higher standards, c) Serbia is becoming an attractive destination for the arrival of new hotel chains, d) increasing trend of

\footnotetext{
Faculty of Economics in Subotica, University of Novi Sad, Segedinski put 9-11, 24000, Subotica, Serbia Faculty of Economics in Subotica, University of Novi Sad, Segedinski put 9-11, 24000, Subotica, Serbia Faculty of Economics in Subotica, University of Novi Sad, Segedinski put 9-11, 24000, Subotica, Serbia
} 
tourism development in the country, e) low tax rates for investors and f) state support for joint ventures (Pavlović, Lazić, \& Cvijanović, 2014). Poldrugovac et al. (2016) emphasize that hotels are in constant struggle to maximize their potential and finding new ways to achieve this. It means that hotel companies will have to adapt to a number of changes in order to produce and offer appropriate products (Redžić, 2018). One of the most important goals for every company, as well as, hotel is maximizing profit and controlling expense level. Analyzing profitability indicators, managers can understand whether and how a hotel generate profit, or what is their earning power (Luo, Yang, \& Law, 2014). Beside profitability, economic viability is part of the sustainable development strategy of many hotels (Kapiki, Mu, \& Fu, 2014), where hotel must use sustainable development principles to grow revenues and save on costs (Houdré, 2008).

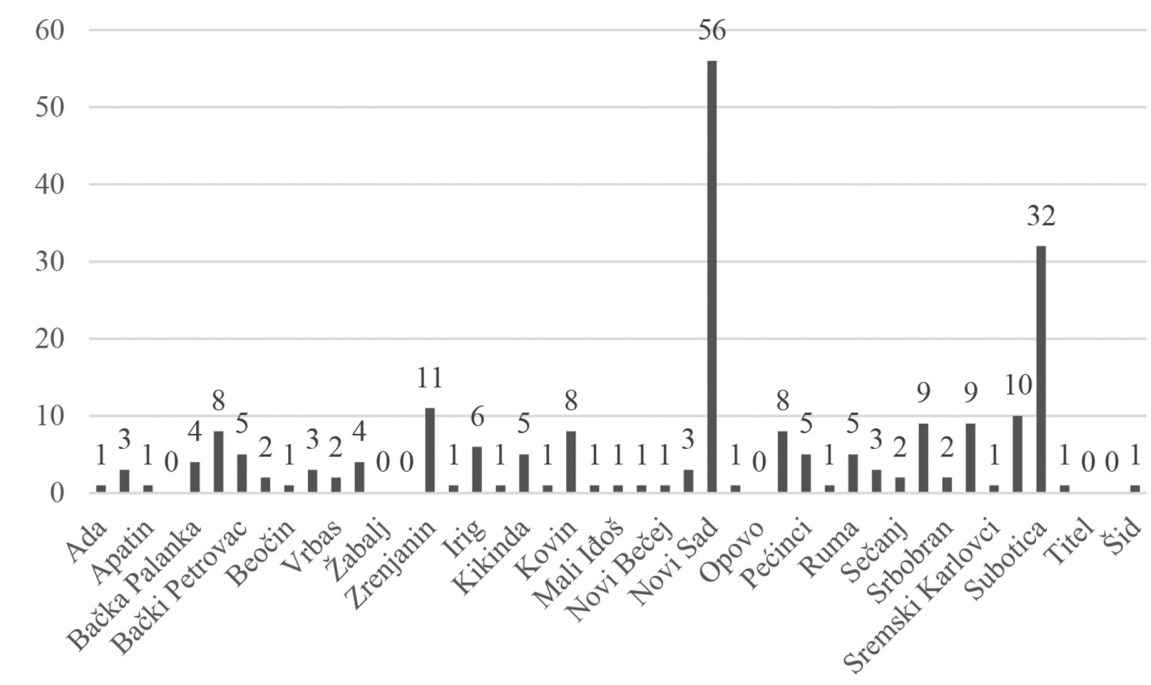

Figure 1. Hotel concentration in AP Vojvodina

Source: Authors' research

Based on Figure 1 we can notice that hotels are concentrated in several municipalities in AP Vojvodina. The highest concentration is in Novi Sad where fifty-six hotels are registered and Subotica with thirty-two hotels. It means that $40 \%$ hotels are concentrated in these cities, while other municipalities have ten or less hotel in the territory of AP Vojvodina.

The structure of this chapter is as follows. After the introduction, there is a literature review where theoretical background enables basis for model creation and definition. The third chapter includes methodology that determines variables and econometric procedures for adequately designed regression models. The fourth chapter analyses hotel profitability in terms of trend in total assets, total capital, return on assets, return on capital, total revenues, total expenses and net result. The next chapter estimates the impact of internal factors on hotels profitability in AP Vojvodina for the period 2014-2018.

\section{LITERATURE REVIEW}

Dimitrić et al. (2018) argue that hotel industry as well as tourism are among the most complex economic activities with a number of determinants on supply and demand sides. First, there are external determinants which include global economic trends, development in the financial sector and climate changes and cultural aspects. Second, internal determinants are those that are influenced by company and depend on the activities and quality of management as well as organ- 
ization structure quality and human potential of the company. Accordingly, the dynamics of the global tourism environment is affected by external factors such as globalisation, new technology, modernisation in transport and communications systems, as well as internal factors such as new tourist demands and more flexible management (Ramón Rodríguez, 2002). Many empirical research includes the most important determinants such as company size, debt level, productivity, liquidity, solvency, profitability, investments etc. (Škuflić \& Mlinarić, 2015). Also, there are empirical studies that have researched how lagged profitability and hotel size affects its profitability (G. Agiomirgianakis \& Magoutas, 2012; Ben Aissa \& Goaied, 2016; Claver-Cortés, Molina-Azorín, \& Pereira-Moliner, 2007; Dimitrić, Tomas Žiković, \& Arbula Blecich, 2019; Nunes, Serrasqueiro, \& Sequeira, 2009; Schmidt, 2014; Stierwald, 2010; Tan, 2017). Empirical analysis of Agiomirgianakis et al. (2013) found that size and leverage have positive and significant impact on profitability of firms in the tourism sector. Further, Zeglat (2008) finds that profitability of hotel sector in UK is positively influenced by sales growth. Ben Aissa and Goaied (2016) identified that hotel profitability is negatively influenced by hotel size and indebtedness level.

\section{METHODOLOGY AND DATA}

For the purpose of research, empirical study analyzed a sample of hotels registered in AP Vojvodina for the period 2014-2018. The empirical research included 478 observations and authors collected and used data from financial statements of hotels based on Scoring.

Table 1. Review of explanatory variables

\begin{tabular}{|l|c|c|}
\hline Variables & Symbol & Calculation \\
\hline Dependent variable & $\boldsymbol{R O A}$ & \\
\hline Return on assets & $\boldsymbol{R O E}$ & \\
\hline Return on equity & CL & Current assets/Short-term liabilities \\
\hline Independent variables & DBT & \\
\hline Current liquidity & FS & Natural logarithm of the total assets \\
\hline Debt & SZ & \\
\hline Financial stability & SGR & Operating revenues - Operating expenses \\
\hline Size & EBIT & \\
\hline Sale growth & LAGROA & \\
\hline Earnings before income and tax & LAGROE & \\
\hline Lagged profitability & Source: Aursed
\end{tabular}

Source: Authors' illustration

\section{PROFITABILITY ANALYSIS OF HOTELS IN AP VOJVODINA}

The first part of research is based on descriptive analysis of key indicators of hotel profitability such as return on assets (ROA) and return on equity (ROE). Descriptive analysis will be conducted through tabular and graphical views for period from 2014 to 2018. After that, potential correlation character and intensity between hotel performance indicators will be measured and evaluated. The third part includes multivariate analysis variance test in order to identify are there significant differences in profitability level of hotels in AP Vojvodina for the period 20142018. Finally, there are multiple regression models to determine the effects of internal factors on profitability of analyzed hotels. The analysis includes internal factors such as current liquidity, debt, financial stability, hotel size, sale growth, earnings before interest and taxes and lagged profitability of analyzed hotels in AP Vojvodina. 


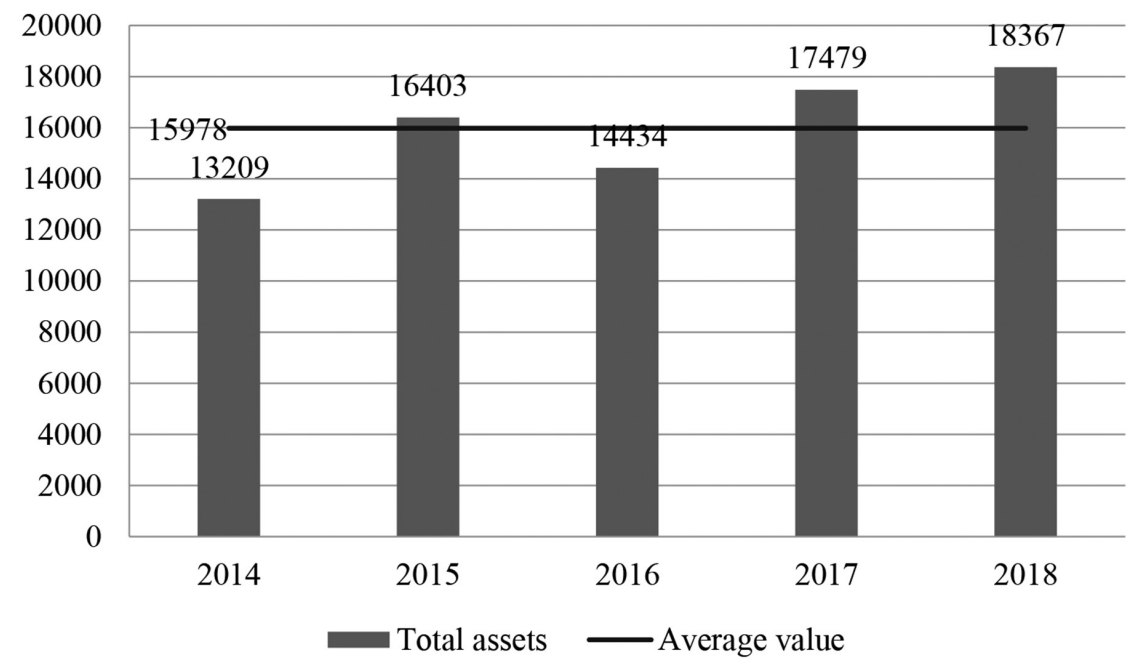

Figure 2. Total assets of hotels in AP Vojvodina (000 RSD)

Source: Authors calculation based on Scoring

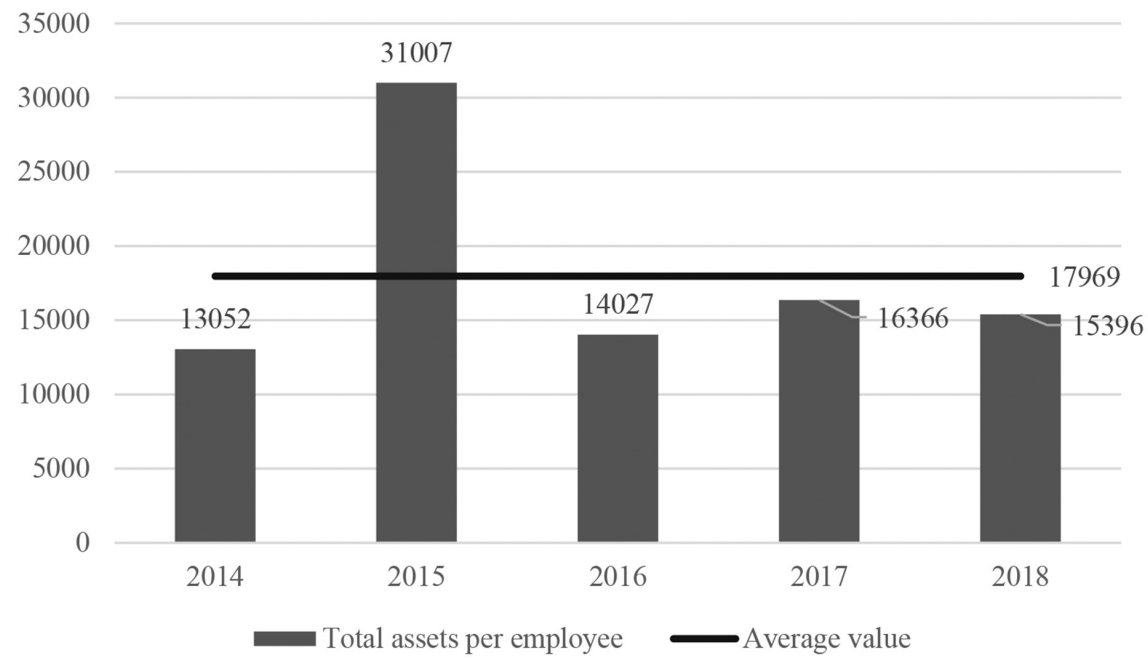

Figure 3. Total assets per employee of hotels in AP Vojvodina

Source: Authors calculation based on Scoring

Analyzing the movement of total assets for the period 2014-2018, we can see that hotels had average value of 15.978.000 RSD. In the last two years, hotels had total assets above average value, where maximum value 18.367.000 RSD is identified in 2018. On the other hand, hotels recorded total assets value below average level in 2014 and 2016. The trend shows that total assets increased for 5.158.0000 RSD from 2014 to the end of the period.

After analyzing total assets of hotels in AP Vojvodina, figure 2 shows total assets per employee from 2014 to 2018. Namely, average total assets of hotels are 17.969 RSD where maximum value of 31.007 RSD identified in 2015. Also, hotels had the smallest total assets per employee in 2014 which is according to trend with movement of total assets and number of employees in the hotel industry.

Figure 4 manifests trend of total capital of hotels in AP Vojvodina from 2014 to 2018. Results showed that average total capital is 7.727.000 RSD where hotels recorded maximum value in 
2015 and 2017. Further, the level of total capital increased for 520.000 RSD in the observed period, although in the last year total capital decreased by 1.609.000 RSD.

Analyzing total capital per employee of hotels in AP Vojvodina for the period 2014-2018, we can notice a decreasingly trend in last two years. The average total capital per employee is 8753 RSD, where maximum value is recorded in 2015 (15238 RSD), where hotels achieved below average value in 2014, 2016, 2017 and 2018.

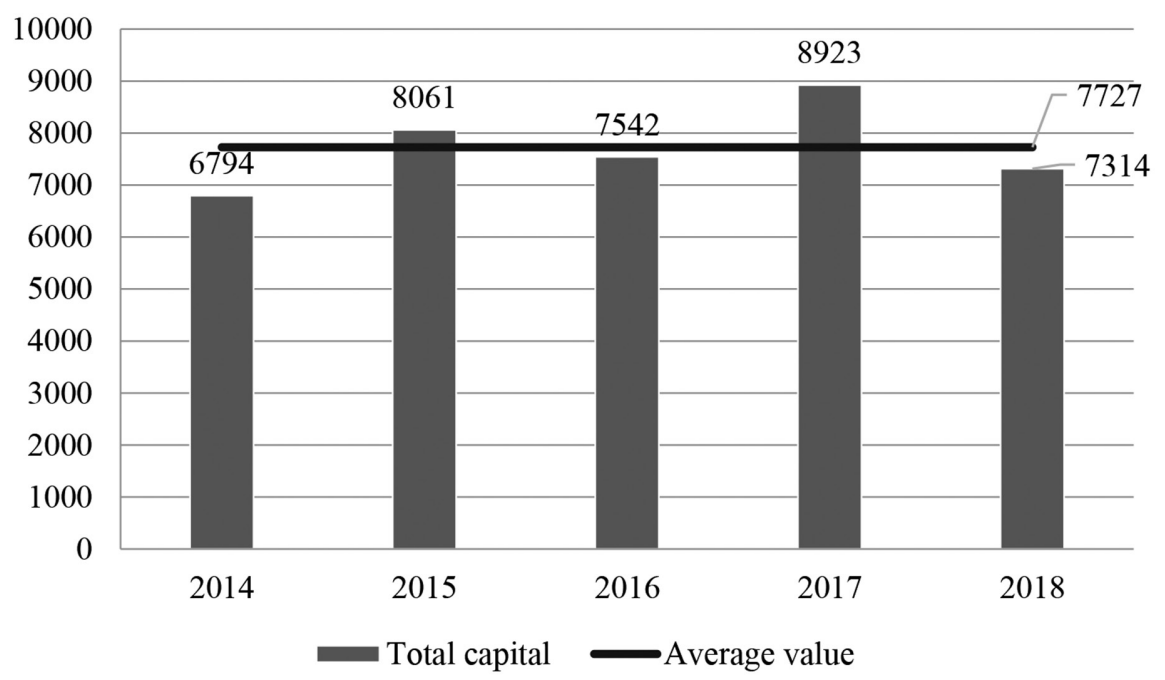

Figure 4. Total capital of hotels in AP Vojvodina (000 RSD)

Source: Authors calculation based on Scoring

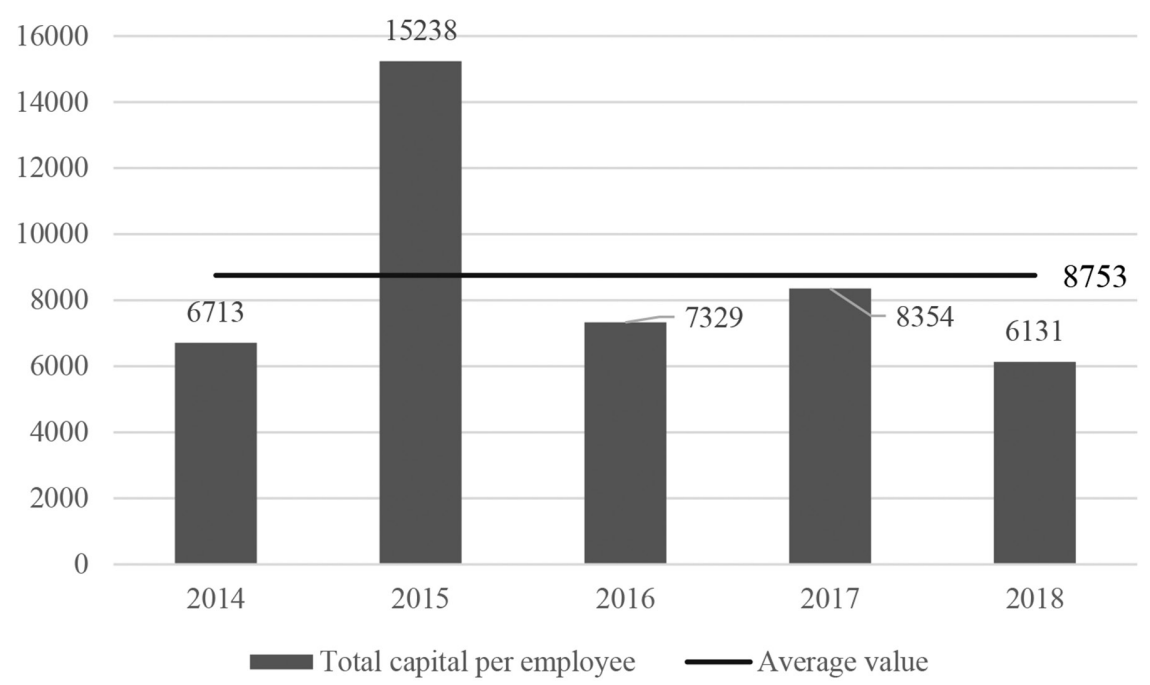

Figure 5. Total capital per employee of hotels in AP Vojvodina

Source: Authors calculation based on Scoring

Figure 6 manifests that hotels in AP Vojvodina are profitable in the observed period measured by return on assets. The average value of ROA is $32.56 \%$ for the period $2014-2018$. Specifically, this indicator is increasing until 2016 when it reaches a maximum value of $66.97 \%$ and after that there is a decrease in value of profitability and ROA is $18.12 \%$ in 2018 . 


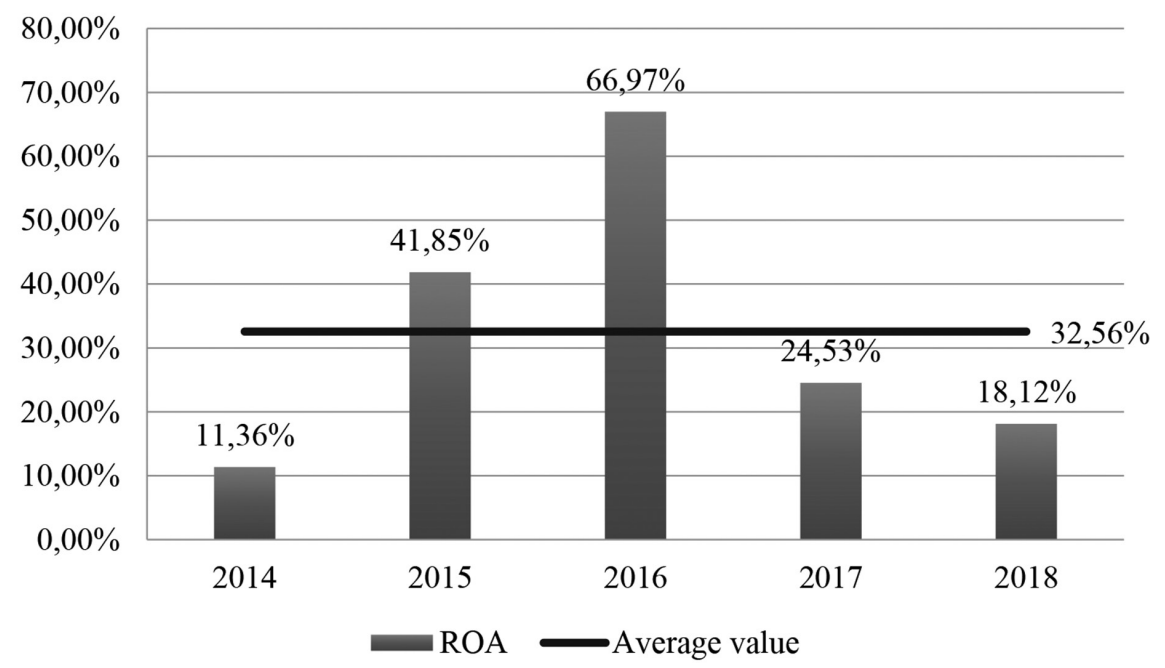

Figure 6. Return on assets of hotels in AP Vojvodina

Source: Authors calculation based on Scoring

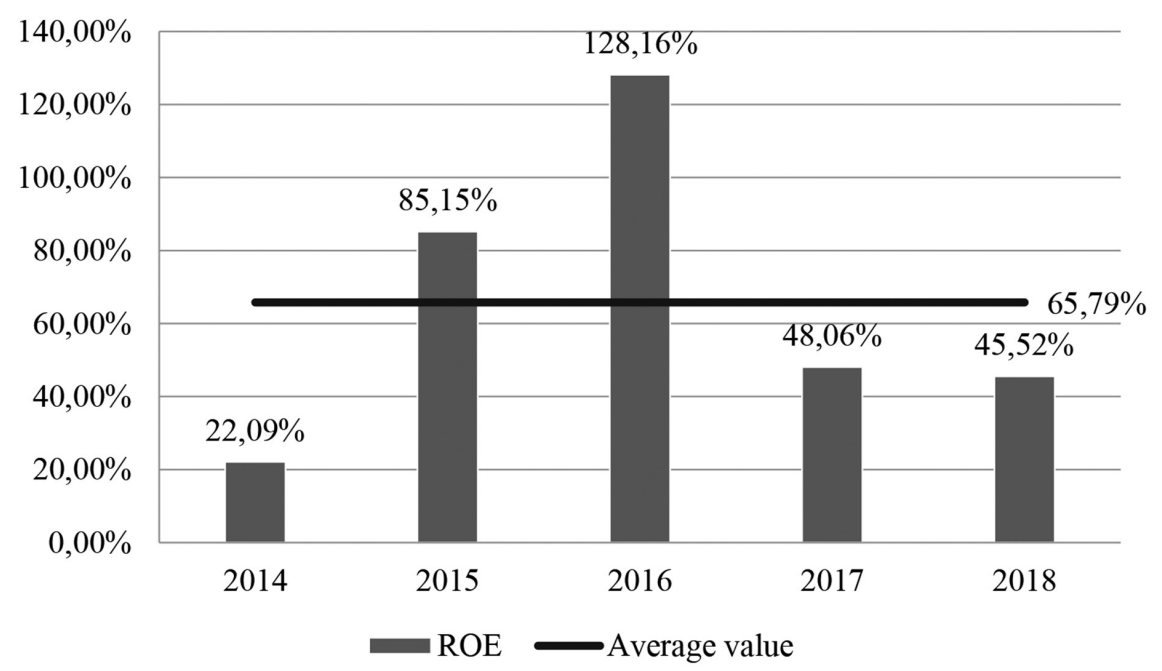

Figure 7. Return on equity of hotels in AP Vojvodina

Source: Authors calculation based on Scoring

Based on profitability trend from figure 7, we can notice that average value of ROE is extremely high at $65.79 \%$. In addition, the high average value of ROE can be associated with 2016 where a maximum value of this indicator was $128.16 \%$. In last two years, the hotels achieved profitability below average level, but it is still higher than profitability at the beginning of the period. In order to identify trend of hotels profitability in AP Vojvodina for the observed period, it is necessary to analyze profitability indicators ROA and ROE through their relative change in a given period.

Dynamic changes in profitability indicators have manifested that change in ROE is more significant than a change in ROA. Namely, profitability indicator expressed through the ratio of net income to average assets for each year increased by $6.76 \%$, while second indicator which includes the ratio of net income and average capital increased by $23.42 \%$.

We can notice that ROE has almost four times increased compare to ROA of analyzed hotels in AP Vojvodina. 
$2014-2018$

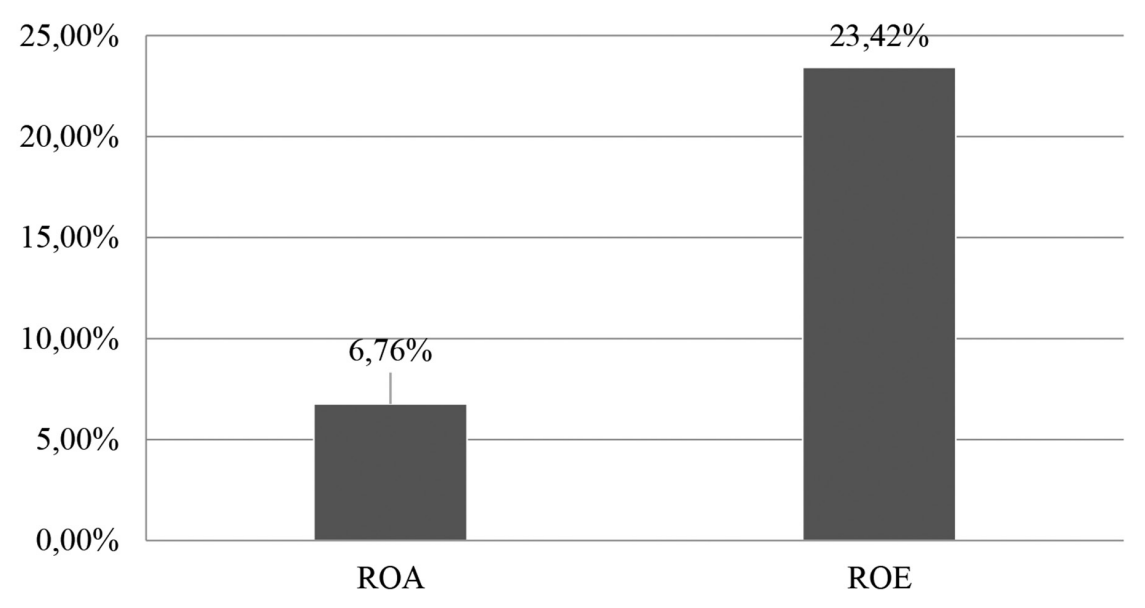

Figure 8. Dynamic changes in ROA and ROE of hotels in AP Vojvodina

Source: Authors calculation based on Scoring

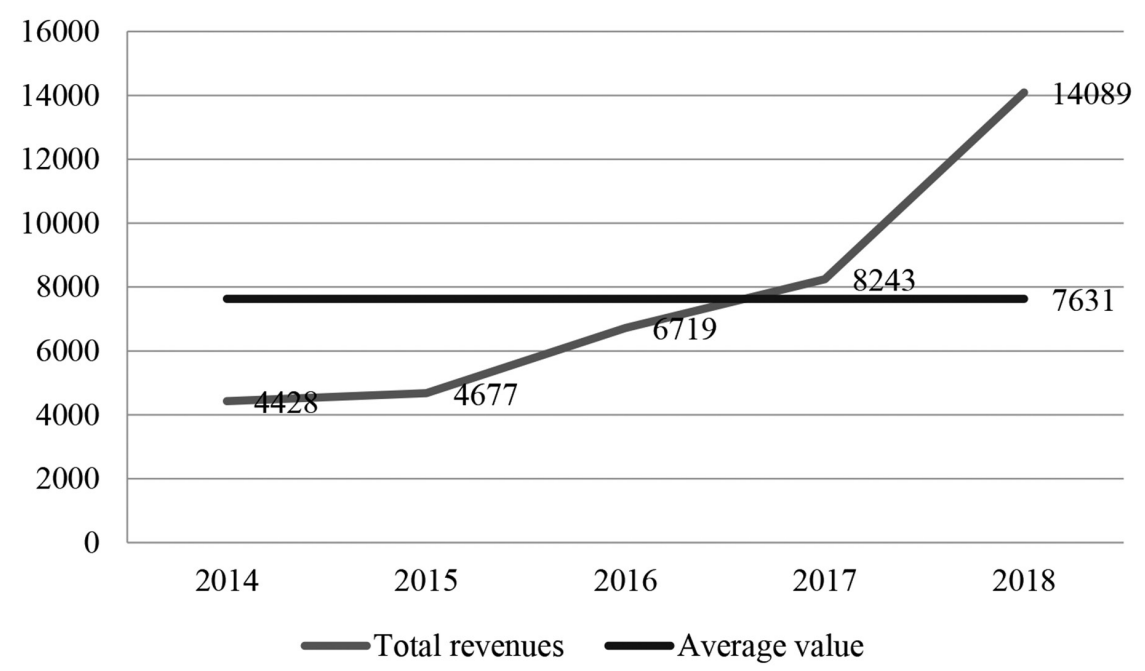

Figure 9. Total revenues of hotels in AP Vojvodina (000 RSD)

Source: Authors calculation based on Scoring

Figure 9 shows movement of total revenues of hotels in AP Vojvodina and the average level was 7.631.000 RSD from 2014 to 2018. In the first three years, total revenues are below the average value, while in 2017 and 2018 hotels recorded revenues level above average value. It is necessary to add expense movement and compare with revenue trends how we determine is current revenues levels enough for operating activities of observed hotels.

The average value of hotel expenses is 8.649.000 RSD for the period 2014-2018. Total expenses had an upward trend with stagnation periods. However, expense growth is slower than revenues growth which is positive for hotel profitability. In the first three years, total expenses are below average level with a growth slightly stagnant between 2015 and 2016.

In the last two tears, total expenses have increased above average level of observed period from 2014 to 2018. 


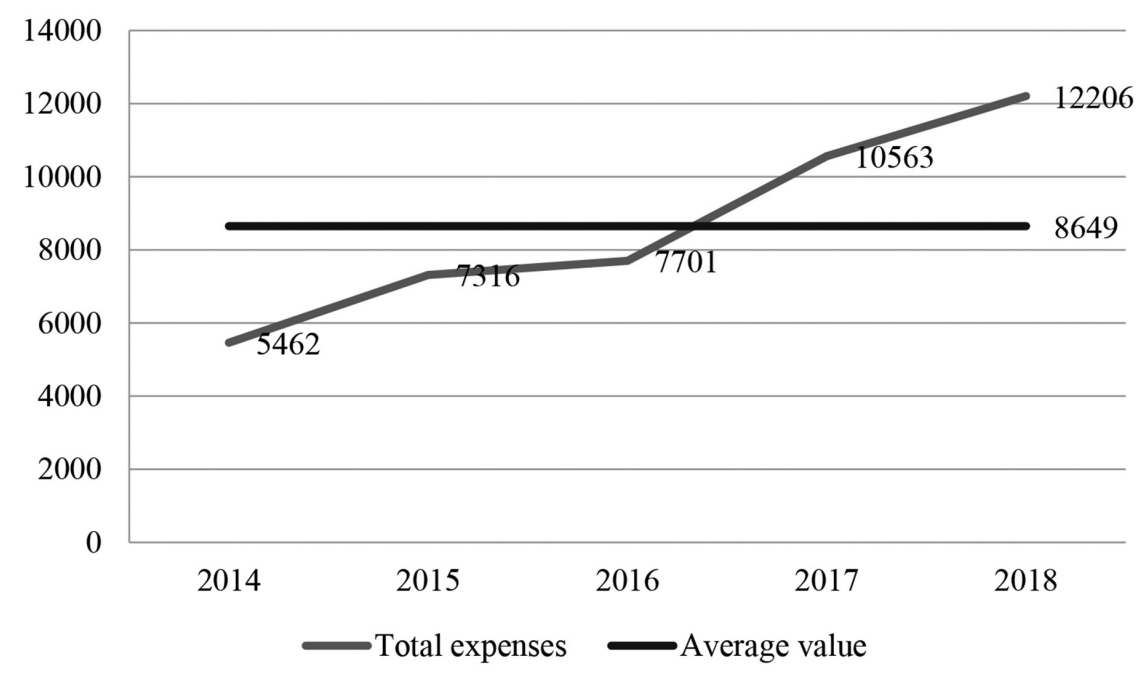

Figure 10. Total expenses of hotels in AP Vojvodina (000 RSD)

Source: Authors calculation based on Scoring

2014-2018

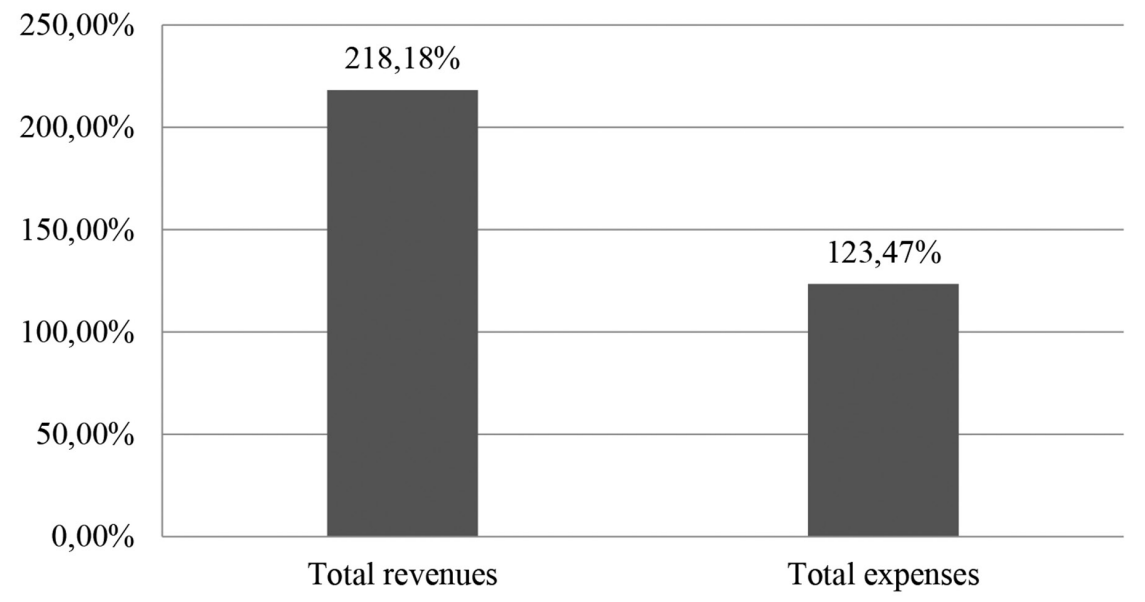

Figure 11. Dynamic changes in total revenues and total expenses of hotels in AP Vojvodina

Source: Authors calculation based on Scoring

Figure 11 shows comparative dynamic changes in total revenues and total expenses of hotels in AP Vojvodina from 2014 to 2018. Empirical analysis reflected that total revenues increased by $218.18 \%$, while total expenses grew by far less intensity and their growth was $123.47 \%$ for the observed period. It can be concluded that total revenues have almost doubled in relation to total expenses of analyzed hotels in AP Vojvodina and this fact can confirm that these hotels are profitable for the period 2014-2018.

Next figure shows movement of EBIT of hotels in AP Vojvodina and hotel industry achieved average EBIT of 1.239.000 RSD from 2014 to 2018. Based on presented figure, it can be concluded that hotels are not profitable at the beginning and end of analyzed period. This means that hotels are not able to cover current operating expenses from current operating income. Also, the hotels are profitable in 2015, 2016 and 2017 and this indicates that profitability is achieved by investment and financing activities and not from operating activities, since hotels did not report losses in those periods. 


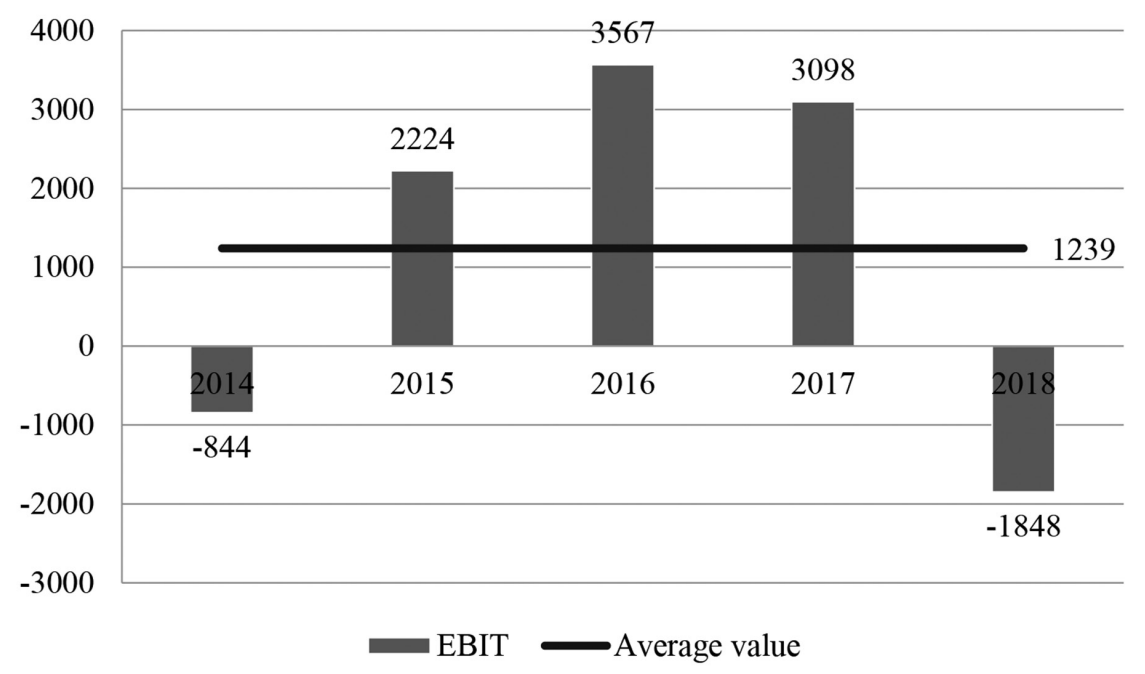

Figure 12. EBIT of hotels in AP Vojvodina (000 RSD)

Source: Authors calculation based on Scoring

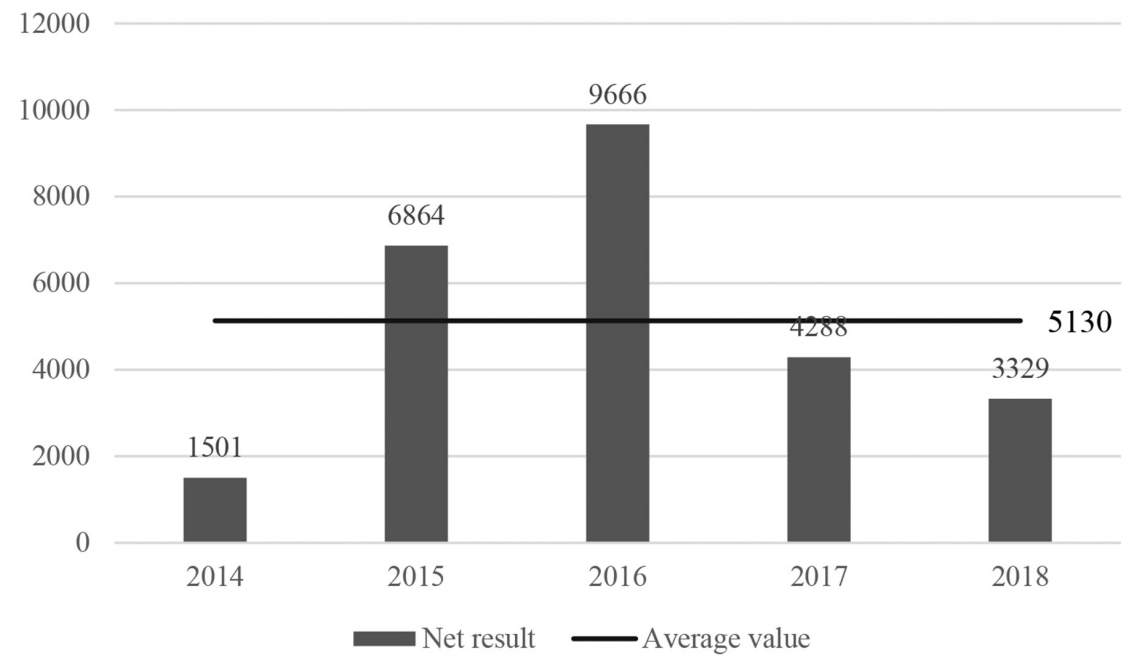

Figure 13. Net result of hotels in AP Vojvodina (000 RSD)

Source: Authors calculation based on Scoring

Figure 13 shows net result of hotels in AP Vojvodina from 2014 to 2018 where average level is 5.130.000 RSD. Bearing in mind that average net result is higher than average EBIT, it can be concluded that high profitability level in the hotel industry is largely achieved by activities of investing and financing. Until 2016 net result increased when the hotels achieved the maximum value of 9.666.000 RSD and after that net result decreased until end of the observed period.

The average value of net result per employee of analyzed hotels is 6.121 RSD. We can notice that in 2015 there was a sharp increase in net result per employee which is a result of the decrease in number of employees in hotels operating in the territory of AP Vojvodina. Observing from 2015 until the end of analyzed period, a lower net result per employee can be explained by their smaller productivity in the hotel industry. 


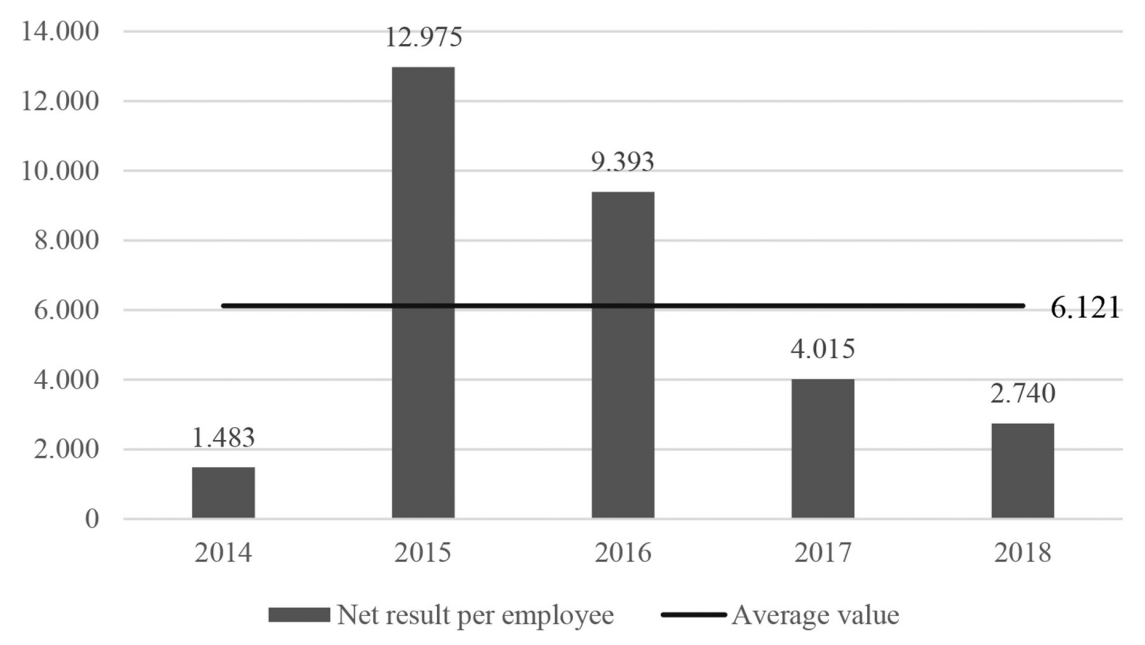

Figure 14. Net result per employee of hotels in AP Vojvodina

Source: Authors calculation based on Scoring

\section{EMPIRICAL RESULTS}

This chapter includes descriptive analysis of key indicators of hotel business in AP Vojvodina. After that, potential correlation character and intensity between hotel performance indicators will be measured and evaluated. The third part includes multivariate analysis variance test in order to identify are there significant differences in profitability level of hotels in AP Vojvodina for the period 2014-2018. Finally, there are multiple regression models to determine the effects of internal factors on profitability of analyzed hotels. The analysis includes internal factors such as current liquidity, debt, financial stability, hotel size, sale growth, earnings before interest and taxes and lagged profitability of analyzed hotels in AP Vojvodina.

Table 2. Descriptive statistics

\begin{tabular}{|l|c|c|c|c|c|}
\hline Variable & Number of obs. & Mean value & $\begin{array}{c}\text { Standard } \\
\text { deviation }\end{array}$ & Minimum value & $\begin{array}{c}\text { Maximum } \\
\text { value }\end{array}$ \\
\hline ROA & 478 & -0.5596772 & 6.277963 & -128.6667 & 5.914 \\
\hline ROE & 478 & -1.421668 & 38.47663 & -793 & 105.72 \\
\hline CL & 478 & 19.51837 & 179.3555 & 0 & 2521.74 \\
\hline DBT & 478 & 7.166871 & 85.01804 & 0 & 1792 \\
\hline FS & 478 & 2.18159 & 13.63284 & 0 & 217.81 \\
\hline SIZE & 478 & 1.636839 & 0.8478075 & 0 & 2.97359 \\
\hline SGR & 478 & 3.521846 & 25.11343 & -1 & 324.6721 \\
\hline EBIT & 478 & 11.77819 & 90.68455 & -528.653 & 741.4549 \\
\hline
\end{tabular}

Source: Authors calculation

Table 2 presents descriptive analysis of hotels in AP Vojvodina in terms of mean value, standard deviation, minimum and maximum value. Based on 478 observations, the results showed positive mean values for all indicators except profitability. Also, current liquidity had the maximum value while earnings per interest and taxes was the lowest. At the same time, current liquidity has the largest standard deviation compared to other variables while on the other hand, variable size had the smallest standard deviation. 
Table 3. Correlation matrix

\begin{tabular}{|c|c|c|c|c|c|c|c|c|c|}
\hline \multicolumn{2}{|c|}{ Correlation } & CL & DBT & FS & ROA & ROE & SIZE & SGR & EBIT \\
\hline \multirow{3}{*}{ CL } & $\begin{array}{l}\text { Pearson } \\
\text { Correlation }\end{array}$ & \multirow{2}{*}{1} & -0.008 & 0.034 & 0.009 & 0.004 & 0.071 & -0.015 & 0.005 \\
\hline & Sig. (2-tailed) & & 0,868 & 0.458 & 0.836 & 0.930 & 0.122 & 0.745 & 0.916 \\
\hline & $\mathrm{N}$ & 478 & 478 & 478 & 478 & 478 & 478 & 478 & 478 \\
\hline \multirow{3}{*}{ DBT } & $\begin{array}{l}\text { Pearson } \\
\text { Correlation } \\
\end{array}$ & -0.008 & \multirow[t]{2}{*}{1} & -0.012 & $-0.248 * *$ & 0.002 & -0.021 & -0.009 & $-0.142 * *$ \\
\hline & \begin{tabular}{|l} 
Sig. (2-tailed) \\
\end{tabular} & 0.868 & & 0.785 & 0.000 & 0.973 & 0.643 & 0.838 & 0.002 \\
\hline & $\mathrm{N}$ & 478 & 478 & 478 & 478 & 478 & 478 & 478 & 478 \\
\hline \multirow{3}{*}{ FS } & \begin{tabular}{|l|} 
Pearson \\
Correlation
\end{tabular} & 0.034 & -0.012 & \multirow[t]{2}{*}{1} & 0.015 & 0.003 & 0.083 & -0.019 & 0.008 \\
\hline & Sig. (2-tailed) & 0.458 & 0.785 & & 0.737 & 0.955 & 0.068 & 0.681 & 0.859 \\
\hline & $\mathrm{N}$ & 478 & 478 & 478 & 478 & 478 & 478 & 478 & 478 \\
\hline \multirow{3}{*}{ ROA } & $\begin{array}{l}\text { Pearson } \\
\text { Correlation }\end{array}$ & 0.009 & $-0.248 * *$ & 0.015 & \multirow[t]{2}{*}{1} & -0.026 & $-0.027 * *$ & 0.002 & 0.007 \\
\hline & Sig. (2-tailed) & 0.836 & 0.000 & 0.737 & & 0.577 & 0.008 & 0.962 & 0.879 \\
\hline & $\mathrm{N}$ & 478 & 478 & 478 & 478 & 478 & 478 & 478 & 478 \\
\hline \multirow{3}{*}{ ROE } & $\begin{array}{l}\text { Pearson } \\
\text { Correlation }\end{array}$ & 0.004 & 0.002 & 0.003 & 0.026 & \multirow[t]{2}{*}{1} & $-0.057 * *$ & 0.007 & $0.141 * *$ \\
\hline & \begin{tabular}{|l} 
Sig. (2-tailed) \\
\end{tabular} & 0.930 & 0.973 & 0.955 & 0.577 & & 0.217 & 0.877 & 0.002 \\
\hline & $\mathrm{N}$ & 478 & 478 & 478 & 478 & 478 & 478 & 478 & 478 \\
\hline \multirow{3}{*}{ SIZE } & $\begin{array}{l}\text { Pearson } \\
\text { Correlation }\end{array}$ & 0.071 & -0.021 & 0.083 & $-0.027 * *$ & $-0.057 * *$ & \multirow[t]{2}{*}{1} & 0.023 & -0.082 \\
\hline & Sig. (2-tailed) & 0.122 & 0.643 & 0.068 & 0.009 & 0.008 & & 0.619 & 0.072 \\
\hline & $\mathrm{N}$ & 478 & 478 & 478 & 478 & 478 & 478 & 478 & 478 \\
\hline \multirow{3}{*}{ SGR } & $\begin{array}{l}\text { Pearson } \\
\text { Correlation }\end{array}$ & -0.015 & -0.009 & -0.019 & 0.002 & 0.007 & 0.023 & \multirow[t]{2}{*}{1} & -0.044 \\
\hline & Sig. (2-tailed) & 0.745 & 0.838 & 0.681 & 0.962 & 0.877 & 0.619 & & 0.342 \\
\hline & $\mathrm{N}$ & 478 & 478 & 478 & 478 & 478 & 478 & 478 & 478 \\
\hline \multirow{3}{*}{ EBIT } & $\begin{array}{l}\text { Pearson } \\
\text { Correlation }\end{array}$ & 0.005 & $-0.142 * *$ & 0.008 & 0.007 & $0.141 * *$ & -0.082 & -0.044 & \multirow[t]{2}{*}{1} \\
\hline & Sig. (2-tailed) & 0.916 & 0.002 & 0.859 & 0.879 & 0.002 & 0.072 & 0.342 & \\
\hline & $\mathrm{N}$ & 478 & 478 & 478 & 478 & 478 & 478 & 478 & 478 \\
\hline
\end{tabular}

**. Correlation is significant at the 0.01 level (2-tailed).

Source: Authors calculation

Table 3. shows correlation matrix between profitability indicators and internal factors of hotel business in AP Vojvodina from 2014 to 2018. Analyzing correlation intensity, we can notice positive correlation between ROA and CL, but not significant. On the other hand, the research showed significant and negative correlation between ROA and SIZE. Also, correlation analysis determined positive correlation between ROE and EBIT and simultaneously negative correlation between ROE and SIZE. Results have shown that hotel size is negatively related to profitability which implies that higher hotels recorded a lower profitability level and inversely.

Table 4. Multivariate analysis results - profitability level by year

\begin{tabular}{|c|c|c|c|c|c|c|}
\hline \multicolumn{2}{|c|}{ Effect } & Value & F & $\begin{array}{c}\text { Hypothesis } \\
\text { df }\end{array}$ & Error df & Sig. \\
\hline \multirow{4}{*}{ Period } & Pillai's Trace & 0.010 & 2.313 & 2.000 & 472.000 & 0.000 \\
\cline { 2 - 7 } & Wilks' Lambda & 0.990 & 2.313 & 2.000 & 472.000 & 0.000 \\
\cline { 2 - 7 } & Hoteling's Trace & 0.010 & 2.313 & 2.000 & 472.000 & 0.000 \\
\cline { 2 - 7 } & Roy's Largest Root & 0.010 & 2.313 & 2.000 & 472.000 & 0.000 \\
\hline
\end{tabular}

Source: Authors calculation 
Considering that obtained value of Pillai's Trace 0.000 is lower than 0.05 , it can be concluded that there is a significant difference in the profitability level of hotels in AP Vojvodina for every year measured by ROA and ROE.

Table 5. Multivariate analysis results - profitability level by hotel

\begin{tabular}{|c|c|c|c|c|c|c|}
\hline \multicolumn{2}{|c|}{ Effect } & Value & F & $\begin{array}{c}\text { Hypothesis } \\
\text { df }\end{array}$ & Error df & Sig. \\
\hline \multirow{4}{*}{ Period } & Pillai's Trace & 0.011 & 1.908 & 2.000 & 351.000 & 0.006 \\
\cline { 2 - 7 } & Wilks' Lambda & 0.989 & 1.908 & 2.000 & 351.000 & 0.006 \\
\cline { 2 - 7 } & Hoteling's Trace & 0.011 & 1.908 & 2.000 & 351.000 & 0.006 \\
\cline { 2 - 7 } & Roy's Largest Root & 0.011 & 1.908 & 2.000 & 351.000 & 0.006 \\
\hline
\end{tabular}

Source: Authors calculation

Further, there is a significant difference in the profitability between analyzed hotels measured by ROA and ROE for the period 2014-2018 because value of Pillai's Trace is lower than reference value of 0.05 .

Table 6. Test of between-subject effects for profitability

\begin{tabular}{|c|c|c|c|c|c|}
\hline \multirow{2}{*}{ Source } & Profitability & $\begin{array}{c}\text { Type III Sum } \\
\text { of Squares }\end{array}$ & df & F & Sig. \\
\hline \multirow{2}{*}{ Period } & ROA & 160.898 & 1 & 4,100 & 0.043 \\
\cline { 2 - 6 } & ROE & 180513.570 & 1 & 0.623 & 0.134 \\
\hline
\end{tabular}

Source: Authors calculation

Based on Table 6 results we can notice that obtained significance result for ROA is less than 0.05 which implies there is a significant difference in this indicator realized by observed hotels in AP Vojvodina. On the other hand, there is no significant difference in the profitability level in terms of ROE, because obtained significance result is higher than 0.05 .

The authors created models of profitability in two steps:

$$
\begin{aligned}
& R O A_{t}=\beta_{0}+\beta_{1} C L_{t}+\beta_{2} D B T_{t}+\beta_{3} F S_{t}+\beta_{4} S Z_{t}+\beta_{5} S G R_{t}+\beta_{6} E B I T_{t}+\beta_{7} L A G R O A_{t} \ldots e_{t} \\
& R O E_{t}=\beta_{0}+\beta_{1} C L_{t}+\beta_{2} D B T_{t}+\beta_{3} F S_{t}+\beta_{4} S Z_{t}+\beta_{5} S G R_{t}+\beta_{6} E B I T_{t}+\beta_{7} L A G R O E_{t}+\ldots e_{t}
\end{aligned}
$$

where are ROA - return on assets; ROE - return on equity: CL current liquidity; DBT - debt; FS - financial stability; SGR - sale growth; EBIT - earnings before interest and taxes, LAGROA - lagged profitability; $\beta 0$ - the constant term, $\beta$ - the coefficient of the independent variables and $\mathrm{e}-$ the error term of the equation.

Table 7. Multicollinearity test

\begin{tabular}{|l|c|c|}
\hline Variable & VIF & 1/VIF \\
\hline LAGROA & 1.03 & 0.9748 \\
\hline DBT & 1.02 & 0.9757 \\
\hline SIZE & 1.01 & 0.9859 \\
\hline FS & 1.01 & 0.9914 \\
\hline CL & 1.01 & 0.9936 \\
\hline SGR & 1.00 & 0.9936 \\
\hline EBIT & 1.00 & 0.9985 \\
\hline Mean VIF & $\mathbf{1 . 0 1}$ & $\mathbf{0 . 9 9 8 9}$ \\
\hline
\end{tabular}

Source: Authors calculation 
In order to identify a potential multicollinearity between independent variables, the empirical study includes Variance Inflation Factor test. Results of VIF test confirmed that there is no high correlation between these variables where the average value is 1.01 . It implies that variable selection is an appropriate and model satisfies condition of multicollinearity absence which is one of the fundamental assumptions in econometric analysis.

Table 8. Multiple regression model of profitability (ROA)

\begin{tabular}{|c|c|c|c|c|c|c|}
\hline Source & SS & df & \multicolumn{2}{|c|}{ MS } & Number of obs. & 478 \\
\hline Model & 1239.0101 & 7 & \multicolumn{2}{|c|}{177.0014} & F $(8,469)$ & 4.74 \\
\hline Residual & 17560.9072 & 470 & \multicolumn{2}{|c|}{37.3636} & Prob $>$ F & 0.0000 \\
\hline Total & 18799.9173 & 477 & \multicolumn{2}{|c|}{39.4128} & R-squared & 0.6059 \\
\hline & & & & & Adj R-squared & 0.5020 \\
\hline & & & & & Root MSE & 6.1126 \\
\hline ROA & Coef. & Std. Err. & $\mathbf{T}$ & $\mathbf{P}>|\mathbf{t}|$ & \multicolumn{2}{|c|}{ [95\% Conf. Interval] } \\
\hline CL & -0.0001 & 0.0015 & -0.13 & 0.001 & -0.0028 & 0.0032 \\
\hline DBT & -0.0188 & 0.0033 & -5.67 & 0.000 & -0.2544 & -0.0123 \\
\hline FS & 0.0047 & 0.0206 & 0.23 & 0.818 & -0.0357 & 0.0452 \\
\hline SIZE & 0.1749 & 0.3324 & 0.53 & 0.599 & -0.4783 & 0.8282 \\
\hline SGR & 0.0004 & 0.1115 & 0.04 & 0.971 & -0.0215 & 0.0223 \\
\hline EBIT & 0.0019 & 0.0030 & 0.65 & 0.518 & -0.0080 & 0.0040 \\
\hline LAGROA & -0.0547 & 0.0452 & -1.21 & 0.227 & -0.1437 & 0.0341 \\
\hline $\mathrm{C}$ & -0.7322 & 0.6120 & -1.20 & 0.232 & -1.9349 & 0.4703 \\
\hline
\end{tabular}

Source: Authors calculation

Table 8 shows the impact of internal factors such as current liquidity, debt, financial stability, hotel size, sale growth and earnings before interest and taxes on return on assets as one of the most important indicators in hotel business. Based on results of multiple regression model, the value of R-squared is 0.6059 which indicates that model explained $60.59 \%$ of independent variables' variations. Empirical results also manifest a significant impact of current liquidity (CL) and debt (DBT) on profitability, while other internal factors don't have a significant effect on return on assets of observed hotels. At the same time, current liquidity and debt negatively affect the hotels profitability where their growth of $1 \%$ decrease profitability level for $0.0001 \%$ and $0.0188 \%$ respectively.

Table 9. Multiple regression model of profitability (ROE)

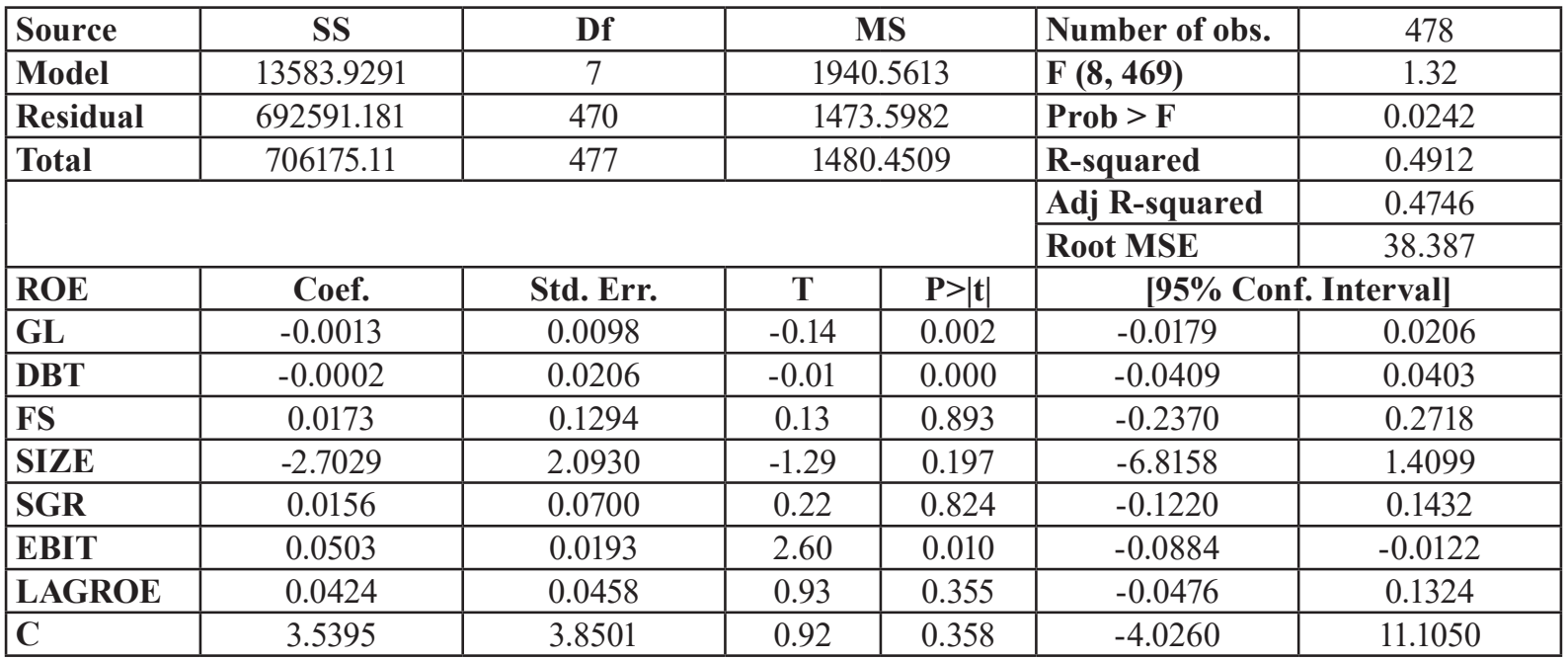

Source: Authors calculation 
After measuring and evaluating the impact of internal factors on return on assets, table shows the effect of current liquidity, debt, financial stability, hotel size, sale growth and earnings before interest and taxes on return on equity of analyzed hotels. Based on results of multiple regression model, R-squared is 0.4912 which implies that model explained $49.12 \%$ of independent variables variations. The model results show a significant effect of current liquidity (CL), debt (DBT) and earnings before interest and taxes (EBIT) on profitability, while other internal factors do not have a significant impact on return on equity of observed hotels. Specifically, CL and DBT negatively affect the hotel profitability, while EBIT has positive implications for return on equity. If liquidity and debt increase by $1 \%$, profitability of hotels will be reduced by $0.0013 \%$ and $0.0002 \%$ respectively. On the other hand, an increase in EBIT by $1 \%$ contributes to an increase ROE for $0.050 \%$.

\section{CONCLUSION}

The chapter has examined the effect of internal factors on profitability of hotels in AP Vojvodina from 2014 to 2018. Empirical analysis has included multivariate analysis of variance as well as multiple regression models which has estimated the impact of current liquidity, debt, financial stability, hotel size, sale growth, earnings before interest and taxes, and lagged profitability. Results of MANOVA test have manifested a significant difference in profitability level between hotels in AP Vojvodina for the period 2014-2018. Observing by individual profitability indicators, there is a significant difference in terms of ROA, while on the other hand, there is no significant difference in terms of ROE. Results of defined models have shown that current liquidity and debt have significant impact on profitability measured by ROA. Also, these factors and EBIT significantly affect the profitability measured by ROE. Specifically, increase of current liquidity and debt declines ROA for $0.0001 \%$ and $0.0188 \%$, as well as declines ROE for $0.0013 \%$ and $0.0002 \%$. Likewise, EBIT positively affect the profitability where increase of this factor raise ROE for $0.050 \%$.

The contribution of this research is quantitative measurement of internal factors on profitability of hotels in AP Vojvodina and this empirical research enables informatical support for hotel management about internal factors that are essential for profitability in the hotel industry. Results have confirmed that hotel management should establish an optimal relationship between liquidity and profitability, as well as decrease debt level in order to create positive implications on profitability level.

\section{ACKNOWLEDGMENT}

The results of this research are part of the project named „Analysis of hotel business in AP Vojvodina in the period from 2014 to 2018". This project was supported by Futurizam doo tourism consulting company and Tourist Organization of Vojvodina [grant number 1324-19].

\section{REFERENCES}

Agiomirgianakis, G. M., Magoutas, A., \& Sfakianakis, G. (2013). Determinants of profitability in the Greek tourism sector revisited: The impact of the economic crisis. Journal of Tourism and Hospitality Management, 1(1), 12-17. Retrieved from https://www.researchgate. net/profile/George_Agiomirgianakis/publication/269993812_Determinants_of_Profitability_in_the_Greek_Tourism_Sector_Revisited_The_Impact_of_the_Economic_Crisis/ links/549d697a0cf2d6581ab63b71/Determinants-of-Profitability-in-the-Greece 
Agiomirgianakis, G., \& Magoutas, A. (2012). Determinants of profitability and the decision-making process of firms in the tourism sector: the case of Greece. International Journal of Decision Sciences, Risk and Management, 4(3-4), 294-299. Retrieved from https:// www.researchgate.net/profile/George_Agiomirgianakis/publication/258540131_Determinants_of_Profitability_and_the_Decision-Making_Process_of_Firms_in_the_Tourism Sector_the_case_of_Greece/links/02e7e52c595a75ff7f000000.pdf

Alčaković, S., Pavlović, D., \& Popesku, J. (2017). Millennials and gamification: A model proposal for gamification application in tourism destination. Marketing, 48(4), 207-214. Retrieved from http://scindeks.ceon.rs/article.aspx?artid=0354-34711704207A

Ben Aissa, S., \& Goaied, M. (2016). Determinants of Tunisian hotel profitability: The role of managerial efficiency. Tourism Management, 52, 478-487. https://doi.org/10.1016/J.TOURMAN.2015.07.015

Claver-Cortés, E., Molina-Azorín, J. F., \& Pereira-Moliner, J. (2007). The impact of strategic behaviours on hotel performance. International Journal of Contemporary Hospitality Management, 19(1), 6-20. https://doi.org/10.1108/09596110710724125

Dimitrić, M., Tomas Žiković, I., \& Arbula Blecich, A. (2019). Profitability determinants of hotel companies in selected Mediterranean countries. Economic Research-Ekonomska Istraživanja, 32(1), 1977-1993. https://doi.org/10.1080/1331677X.2019.1642785

Dimitrić, M., Tomas Žiković, I., \& Matejčić, V. (2018). Profitability determinants in the hotel industry; case of Primorje-Gorski Kotar County and Croatia. Financije-Teorija i Suvremena Pitanja. Ekonomsku Fakultet u Osijeku, 329-350.

Dragićević, V., Jovičić, D., Blešić, I., Stankov, U., \& Bošković, D. (2012). Business tourism destination competitiveness: A case of Vojvodina Province (Serbia). Economic Research-Ekonomska Istraživanja, 25(2), 311-332. Retrieved from https://hrcak.srce.hr/file/128945

Houdré, H. (2008). Sustainable Development in the Hotel Industry. Cornell Hospitality Industry Perspectives, 1(2), 6-20. Retrieved from https://scholarship.sha.cornell.edu/chrindper/2

Kapiki, S., Mu, L., \& Fu, J. (2014). Assessment of the lodging industry profitability performance: Invest in independent or chain ownership? Turizam, 18(2), 84-94. Retrieved from https://papers.ssrn.com/sol3/papers.cfm?abstract_id=2459498

Luo, H., Yang, Y., \& Law, R. (2014). How to achieve a high efficiency level of the hotel industry? International Journal of Contemporary Hospitality Management, 26(8), 1140-1161. https://doi.org/10.1108/IJCHM-01-2013-0050

Mašić, S. (2013). The Performance of the Serbian Hotel Industry/Performanse Hotelskog Poslovanja U Srbiji. Singidunum Journal of Applied Sciences, 10(2), 24-31. Retrieved from https:// www.degruyter.com/downloadpdf/j/sjas.2013.10.issue-2/sjas10-4481/sjas10-4481.xml

Milenković, N., Andrašić, J., \& Kalaš, B. (2017). Finansijska analiza sektora turizma-primer ugostiteljskih preduzeća severa Vojvodine. In MODERN MANAGEMENT TOOLS AND ECONOMY OF TOURISM SECTOR IN PRESENT ERA (pp. 197-212). Association of Economists and Managers of the Balkans-UDEKOM.

Nunes, P. J. M., Serrasqueiro, Z. M., \& Sequeira, T. N. (2009). Profitability in Portuguese service industries: a panel data approach. The Service Industries Journal, 29(5), 693-707. https://doi.org/10.1080/02642060902720188

Pavlović, D., Lazić, J., \& Cvijanović, J. (2014). Serbian hotel industry development. Hotel and Tourism Management, 2(1), 11-19. Retrieved from https://www.ceeol.com/search/article-detail?id=730675

Poldrugovac, K., Tekavcic, M., \& Jankovic, S. (2016). Efficiency in the hotel industry: an empirical examination of the most influential factors. Economic Research-Ekonomska Istraživanja, 29(1), 583-597. https://doi.org/10.1080/1331677X.2016.1177464 
Ramón Rodríguez, A. (2002). Determining factors in entry choice for international expansion. The case of the Spanish hotel industry. Tourism Management, 23(6), 597-607. https://doi. org/10.1016/S0261-5177(02)00024-9

Redžić, D. (2018). Significance of quality in the tourism industry: Research study on the perception of stakeholders in tourism. Hotel and Tourism Management, 6(2), 11-20. Retrieved from https:/www.ceeol.com/search/article-detail?id=725954

Schmidt, N. (2014). The determinants of firm profitability: the effect of social media. Claremont Colleges, CMC Senior Thesis. Retrieved from http://scholarship.claremont.edu/cgi/viewcontent.cgi?article $=1882 \&$ context $=$ cmc_theses

Škuflić, L., \& Mlinarić, D. (2015). Mikroekonomske determinante profitabilnosti Hrvatske hotelske industrije. Ekonomski Pregled, 66(5), 477-494. Retrieved from https://hrcak.srce.hr/ index.php?show $=$ clanak\&id_clanak_jezik $=217468$

Stierwald, A. (2010). Determinants of profitability: An analysis of large Australian firms (Melbourne Institute Working Paper 1/10 No. 1). Retrieved from https://papers.ssrn.com/sol3/ papers.cfm?abstract_id $=1632749$

Tan, Y. (2017). Hotel-specific, industry-specific and macroeconomic determinants of profitability in London Hotel industry: Structure-Conduct-Performance or Efficient-Structure. Available at SSRN: Https://Ssrn.Com/Abstract=2943487 or Http://Dx.Doi.Org/10.2139/ Ssrn.2943487.

Zeglat, D. (2008). An investigation of the relationship between service quality and profitability in the UK budget hotel sector. Doctoral dissertation, University of Surrey. 